\title{
REMARKS ON THE POSITION OF SOME AUSTRALIAN ACANTHACEAE
}

\author{
C. E. B. BREMEKAMP
}

(Botanical Museum and Herbarium, Utrecht)

(received February 14th, 1962)

Last year Mr. G. Chippendale, botanist to the Animal Industry Branch of the Northern Territory Administration, Alice Springs, Australia, asked my opinion on some Acanthaceae collected in the Northern Territory. They belonged to species which in the more recent Australian floras are included in the genera Ruellia $\mathrm{L}$ and fusticia L. The first of these two genera is in the delimitation accepted by BREMEKAMP and NANNENGA-BREMERAMP (A preliminary survey of the Ruelliinae of the Malay Archipelago and New Guinea, Verh. Kon. Ned. Akad. v. Wetensch., Afd. Natuurk. 2nd Sect. XLV, no 1: 8-10, 1948) confined to America, whereas the second (cf. BREMEKAMP, Notes on the Acanthaceae of Java, Verh. Kon. Ned. Akad. v. Wetensch., Afd. Natuurk. 2nd Sect. XLV, no 2: 4-5, 1948) is found in Africa only.

Of the six specimens which Mr. Chippendale sent me at the beginning of last year two proved to represent a new species of Dipteracanthus Nees emend. Brem., whereas the four others could be included in Rostellularia pogonanthera F. v. Müll. The thirteen specimens which I received a few months later, belonged for the greater part to Dipteracanthus, and among them a new variety of $\mathbf{D}$. corynothecus (F. v. Müll. ex Bth.) Brem. comb. nov. (Ruellia corynotheca F. v. Müll. ex Bth.) proved to be represented. However, the set included also a specimen of the very rare Fusticia kempeana F. v. Müll, collected at Ooraminna rockhole, N.T. (Chippendale 6649). Unlike most of the other Australian "Zusticia" species, it can not be included in Rostellularia Reichenb., but has to be removed to a genus of its own, for which I propose the name Sarojusticia; this genus is apparently not represented outside Australia.

Of the Ruelliinae occurring in Australia the nearly allied Ruellia acaulis $\mathrm{R}$. Br., $R$. australis Cavan. and $R$. pumilio $\mathrm{R}$. Br. will have to be removed, as indicated in the work quoted above (p. 26), to a genus of their own, which seems to be confined to Australia, whereas the position of $R$. spiciflora F. v. Müll. has not yet been settled. The classification of the remaining species offers no difficulties; it appears that they can all be included in Dipteracanthus Nees emend. Brem.

The four species mentioned by name in the preceding paragraph were included by Domin in Aporuellia Clarke, but this genus can not be maintained as the type species, $A$. axillaris Clarke, proved to be either identical with or at least a very near ally of Dipteracanthus 
ventricosus Nees. The second species which Clarke included in this genus, viz. A. sumatrensis Clarke, was selected by Bremekamp and Nannenga-Bremekamp as type of a new genus Pararuellia (l.c. p. 15), in which there is certainly no place for Ruellia acaulis, $R$. australis and $\boldsymbol{R}$. pumilio, though it is not entirely excluded that $R$. spiciflora, which is known to me from the description only, may belong to it.

The genus Dipteracanthus Nees emend. Brem. differs from Ruellia $L$ emend. Brem. in the arrangement of the flowers, which are inserted either singly, in triads or in very strongly condensed few-flowered dichasia, occasionally accompanied by one or two superposed ones, in the axil of ordinary leaves, by the size of the bracteoles, which are longer than the calyx, and by the unguiculate capsules. The new species from the Northern Territory may be characterized as follows.

Dipteracanthus sessiliflorus Brem. spec. nov. a D. primulaceo (F. v. Müll. ex Bth.) Brem. comb. nov. (Ruellia primulacea F. v. Müll. ex Bth.) et a D. corynotheco (F. v. Müll. ex Bth.) Brem. floribus sessilibus et pro parte in dichasia dispositis distinguenda, a $D$. primulaceo insuper foliis minoribus et capsula utroque loculo seminibus 4 ad basin aggregatis instructa, a $D$. corynotheco caule erecto, floribus majoribus et capsula latiore diversa.

Suffrutex circ. $25 \mathrm{~cm}$ altus, ramosior, ramis veterioribus cortice griseo rimoso vestitis et usque ad $4.5 \mathrm{~mm}$ diam. Rami novelli pilis curvatis acroscopis densius pubescentes, circ. $1 \mathrm{~mm}$ diam., ex internodiis $1.0-2.5 \mathrm{~cm}$, raro usque ad $3.5 \mathrm{~cm}$ longis compositi. Folia in petiolum pubescentem, circ. $4 \mathrm{~mm}$ longum contracta; lamina elliptica vel elliptico-oblonga, $0.9-1.3 \mathrm{~cm}$ longa et $0.5-0.7 \mathrm{~cm}$ lata, apice subobtusa, basi ad petiolum contracta, margine undulata, sicc. luteoviridis, utrimque pilis curvatis pubescens, nervis utroque latere costae plerumque 3 vel 4 , prominulis. Flores axillares vel in dichasia sessilia, e floribus 3-7 composita dispositi; flores ipsi semper sessiles. Bracteolae foliis similiores sed minores, apicem rami versus gradatim breviores et ad postremum interdum calyce vix longiores. Calycis lobi lineares, $5 \mathrm{~mm}$ longi, acute exeuntes, pubescentes. Corolla lilacina, $25 \mathrm{~mm}$ longa, extus sparse pilosa, e tubo $3 \mathrm{~mm}$ longo et $2.5 \mathrm{~mm}$ diam., fauce campanulato $15 \mathrm{~mm}$ longo et $5 \mathrm{~mm}$ diam. et lobis obtusis $7 \mathrm{~mm}$ longis composita. Filamenta glabra 3 et $5 \mathrm{~mm}$ longa; antherae $2 \mathrm{~mm}$ longae. Granula pollinis alveolata et probabiliter sparsipora, 45-48 $\mu$ diam. Ovarium glabrum, utroque loculo ovulis 4 instructo. Stylus hirtellus. Capsula unguiculata glabra, $15 \mathrm{~mm}$ longa et $7.5 \mathrm{~mm}$ lata, retinaculis acutis $2 \mathrm{~mm}$ longis ad basin dissepimenti insertis. Semina ipsa nondum visa.

Australia, Northern Territory: White Range, 4 miles NE of Arltunga Mission, Ghippendale 4103, typus florifer; Harts Range, 6 miles S of Police Station, id. 3487, co-typus fructifer.

As mentioned above the second set of specimens sent by Mr. Chippendale contained some representatives of a new variety of $D$. corynothecus. This variety possesses a corolla of the same size as that of 
$D$. primulaceus, which means that it is much larger than that of the typical form of $D$. corynothecus, but it differs from that of $D$. primulaceus because it is not suddenly and very conspicuously widened at the insertion of the stamens; this variety differs also from $D$. primulaceus because the number of ovules per ovary cell is not 6 but 4 ; in these characters as well as in general aspect it agrees with the typical D. corynothecus.

Dipteracanthus corynothecus (F. v. Müll. ex Bth.) Brem. var. grandiflorus Brem. var. nov., corolla circ. $4 \mathrm{~cm}$ longa a typo recedens. Australia, Northern Territory: Mt Undoolya area, 20 miles E of Alice Springs, Chippendale 429, typus var. in Herb. North. Terr.; 15 miles SE of Stirling, Johnson 4035 in Herb. North. Terr.; 16 miles SE of Alice Springs, Winkworth 683 in Herb. CANB, Canberra.

The identity of the four Rostellularia specimens collected in the Northern Territory (near Ulambaro Spring, Haast's Bluff, Chippendale 2586; 12.5 miles $S$ of Deep Well Siding, id. 2720; 6 miles $S$ of Harts Range Police Station, id. 3444; 2 miles NE of Ammaroo H.S., id. 3679) was rather difficult to establish. They proved to be very similar to some specimens from New South Wales which our herbarium had received at an earlier occasion (Mt Harris Station, 40 miles NNW of Warren, Constable 20341; Bachyama State Forest, 15 miles NE of Forbes, Curtis 23544; Preservation Creek, Mt Poole Station, 10. miles W of Milparinha, Johnson and Constable 39810). These specimens from New South Wales are somewhat less densely hairy, but show no other points of difference with those from the Northern Territory. They were received here under the name Justicia procumbens $L$, which is Rostellularia procumbens (L) Nees.

It is noteworthy that the description of "fusticia procumbens" given by Bentham in his "Flora Australiensis" (IV: 549), and copied verbally by Bailey in his "Queensland Flora" (IV: 1151), has apparently been based on Asiatic material. In the Australian specimens of Rostellularia species which I could investigate, the fifth calyx lobe was always absent, and the bracts, bracteoles and calyx lobes were always provided with a distinct hyaline margin, and this is not so in the Indian specimens that have rightly been referred to $R$. procumbens. Although this species has repeatedly been reported from other regions (Indo-China, Malaysia), it is known with certainty from India only (see my "Notes on the Acanthaceae of Java, p. 61 and 62 , and the notes attached to the description of $R$. neglecta Brem. and to that of $R$. ramosissima Brem. in my list of Acanthaceae collected by the Danish Expedition to Thailand (1957/58) in Dansk Botanisk Arkiv 20: 86 and 87 (1961). Other points of difference between the Australian plants that have been referred to $R$. procumbens and the true $R$. procumbens from India are found in the indumentum. Although the number of hairs in the Australian specimens may vary, they are always much shorter and softer than those of the true $R$. procumbens. Moreover, the cystoliths in the leaves are in the Australian specimens almost all 
directed parallel to the midrib, and only a very small part of them are "boomerang-shaped", whereas they are in the leaves of the true $R$. procumbens nearly all "boomerang-shaped" and transversely oriented, the bracts, bracteoles and calyx lobes being the only parts in which they are for the greater part longitudinally directed and straight. In view of the fact that the distribution area of the better known Rostellularia species is always rather small, it does not look probable that an Indian species like $R$. procumbens would occur in Australia, or that one or more of the species that are found in the last-mentioned area would be near allies of such a species. In this connection it is noteworthy that the three "Fusticia" species which R. Brown had recognized in his "Prodromus", viz. F. juncea, f. media and $\mathcal{7}$. adscendens, and which were all three included by Bentham in 7. procumbens, were described by Brown as provided with a "calyx 4-partitus". In this respect they agree therefore with the specimens quoted above, which seems to exclude the possibility that they are near allies of Rostellularia procumbens.

However, the Rostellularia specimens quoted above differ from $\boldsymbol{R}$. procumbens not only in the total suppression of the fifth calyx lobe, in the hyaline margin of the bracts, bracteoles and calyx lobes, and in the shortness of the hairs by which their stems and leaves are covered, but also in the presence of hairs on the dorsal side of the anthers, a peculiarity which was noticed also by F. von Müller in the specimen on which he based his Rostellularia pogonanthera, the specific epithet of which means "with bearded anthers". As this character is, as Von Müller rightly remarked, not found in any other species of this genus, it is very probable that the specimens mentioned above belong to this species; in other points too they appear to answer the description given by Von Müller.

Of the "Fusticia" species described by Von Müller $\mathcal{F}$. cavernarum and $\mathcal{F}$. eranthemoides must doubtless be included in Rostellularia, but the position of his 7 . hygrophiloides remains uncertain. Von Müller himself refers it to a section Adhatoda, which is based on the type of the genus Adhatoda Nees, but this is doubtless a mistake, as the inflorescences of Adhatoda are provided with a long preduncle and as its anthers are of an entirely different kind. Fusticia hygrophiloides probably represents an as yet undescribed genus.

Some years later Von Müller described another species, viz. Justicia kempeana, and as there was among the specimens which I received from Mr. Chippendale a specimen collected at Ooraminna rockhole, south of Alice Springs, which could be referred to this species, I can formulate my views on the position of the latter with greater precision. It appears that it represents a distinct genus which differs from Rostellularia in the following points.

The cystoliths in the leaves are all straight and rather short, and most of them are directed towards the margin or somewhat more towards the tip of the leaf. However, this character is perhaps of secondary importance only, as the cystoliths in the leaves of the Rostellularia species too vary, although they are always larger than those 
found in the leaves of Fusticia kempeana, and although at least a part of them are always "boomerang-shaped". When we pass on to the inflorescence, we note that the latter differs rather conspicuously from the dense spike found in Rostellularia. The bracts and bracteoles are leaf-like, the bracts being hardly distinguishable from the ordinary leaves, which however are very small in this species. The bracteoles are about half as long as the bracts, but of similar shape, i.e. with a few teeth along the margin. Such teeth are never found in the bracteoles of Rostellularia. The calyx is 5-partite, and the lobes are all of the same size and shape, a situation which is never found in Rostellularia. The calyx lobes are in the lower part provided with a hyaline margin, which gradually becomes narrower; on the outside they are covered with very minute conical bristles, which increase somewhat in size and in frequency towards the margin, but the calyx lobes can hardly be called ciliolate and are certainly not ciliate. The filaments do not show a contraction at the top, and the lumen of the pollen grains is not distinctly sandglass-shaped. The ovary is never comose, but completely glabrous. The retinacula are not widened at the top. The seed is carunculate, but this is not of much importance, as such seeds are found also in some Rostellularia species.

It agrees with Rostellularia in the following points.

The spikes are terminal, but this is a character which is found in several other genera of the fusticiinae too. The corolla is short and provided with a rugula whose margin is in the lower part provided with cilia; the lower lip is provided with a palate consisting of two parallel bulges ornamented with coloured veins, but this is of secondary importance as such a rugula and palate are general characters of the Fusticiinae; the upper lip is deltoid and emarginate, and the incisions between the two lips are deeper than those between the three lobes of the lower lip. The filaments are flattened and glabrous, and descend into the tube in the form of two ciliate ridges; the connective is oblique, and the lower theca is provided with a long spur; the pollen grains are doleiform, flattened and 2-porous with a single row of knobs on each side of the pore. The urceolate disk is provided with two small quadrate appendages. The capsule is 4-seeded, small and, although provided with a solid base, not distinctly unguiculate.

On the one hand we see therefore an unmistable resemblance with Rostellularia, on the other hand there are differences of such importance that an inclusion of this species in Rostellularia can not be regarded as justified. Therefore, it will have to be referred to another genus, and as not one of the other genera of the Fusticiinae that so far have been recognized, comes nearer to fusticia kempeana than Rostellularia itself, this species will have to be transferred to an entirely new genus. I propose for the latter the name "Sarojusticia" in which the "broomlike" aspect of the species on which it is based and which so far is its only representative, is reflected.

Sarojusticia, genus Justiciinarum adhuc monotypicum, Rostellulariae Reichenb. affine, sed bracteis bracteolisque foliaceis et margine 
dentatis, calyce aequaliter 5-partito, filamentis apice non contractis, granulis pollinis lumine ad medium non distincte constricto instructis, ovario non comoso, retinaculis apice non dilatatis ab eo recedens.

Suffrutex parvus. Ramuli puberuli. Folia parva, crenato-dentata. Flores in spicas laxas dispositi. Bracteae bracteolaeque foliaceae, crenato-dentatae. Calyx aequaliter 5-partitus, lobis dimidio inferiore hyalino-marginatis. Corollae labium superum deltoideum, emarginatum; labium inferum trifidum. Stamina filamentis apice non contractis, antheris connectivo obliquo instructis, theca inferiore longe calcarata. Granula pollinis doleiformia; lumen ad medium non distincte constrictum. Discus urceolatus, margine in appendices duas quadratas productus. Capsula non distincte unguiculata, parte basali tamen solida, 4-seminalis. Semina carunculata.

Species typica: Sarojusticia kempeana (F. v. Müll.) Brem. comb. nov. (Justicia kempeana F. v. Müll.).

Habitat Australiae partem septemtrionalem.

\section{SUMMARY}

The taxonomic position of some Australian Ruelliinae and Justiciinae is discussed. In Dipleracanthus two new combinations are proposed, viz. D. primulaceus (F. v. Müll. ex Bth.) Brem. and D. corynothecus (F. v. Müll. ex Bth.) Brem., both originally described in Ruellia, and one new species and one new variety are described, viz. D. sessiliflorus Brem. and $D$. corynothecus (F. v. Müll. ex Bth.) Brem. var. grandiflorus Brem. The Australian specimens that hitherto have been referred to Justicia procumbens L (= Rostellularia procumbens (L) Nees) will have to be referred to various other Rostellularia species. Fusticia kempeana F. v. Müll. is removed to a new genus Sarojusticia, which necessitates the new combination S. kempeana (F. v. Müll) Brem. 